\title{
Short-term use of metamizole sodium versus diclofenac sodium in acute renal colic pain in Turkish patients; a double-blind, observational study
}

\section{Akut renal kolik ağrisı olan Türk hastalarda kısa süreli metamizol sodyum ile diklofenak sodyum tedavilerinin karşılaștırılması; çift kör, go̊zlemsel bir çalıșma}

\author{
Mehmet Kürşat DERici ${ }^{1}$, Hakan ERGÜN²
}

\section{ABSTRACT}

Objective: Renal colic pain is one of the most frequent reasons for emergency department visits. Metamizole sodium and diclofenac are the most common used non-narcotic drugs in available countries. The objective of this study was to compare the effectiveness and safety of metamizole sodium and diclofenac in treatment of acute renal colic pain in emergency room services in Ankara, Turkey.

Methods: Eighty-eight patients with renal colic were treated intramuscularly (i.m.) with metamizole sodium (1 g) $(n=48)$ or diclofenac sodium $(75 \mathrm{mg})(\mathrm{n}=40)$. Pain intensity was measured by using visual analogue scale $(0-100 \mathrm{~mm})$ and 5-point verbal score before (baseline) and after 30, 60, 90 and 120 minutes of i.m. drug administration.

Results: Both of the treatment groups were homogeneous when analyzed by age, sex and baseline pain intensity. Both treatments were well tolerated and none of the observed side effects were serious. Five patients in the metamizole sodium and three patients in the diclofenac group needed extra treatment. The average pain intensity difference between groups for all time points measured was not significantly different. There was no significant difference in physician and patient evaluations for both drugs.

\section{ÖZET}

Amaç: Renal kolik ağrısı, acil servis başvurularının en sık nedenlerinden biridir. Metamizol sodyum ve diklofenak, ilaçların bulunduğu ülkelerde en yaygın kullanılan narkotik olmayan ilaçlardır. Bu çalıșmanın amacı, Ankara'daki acil servislerde akut renal kolik ağrısının tedavisinde metamizol sodyum ve diklofenak'ın etkinliğini ve güvenliğini karșılaștırmaktır.

Yöntem: Renal kolik ağrısı olan 88 hasta intramüsküler metamizol sodyum ( $1 \mathrm{~g})(\mathrm{n}=48)$ veya diklofenak sodyum (75 mg) (n=40) ile tedavi edildi. Ağrı șiddeti, ilaç uygulanmadan önce (başlangıç düzeyi) ve uygulandıktan 30, 60, 90 ve 120 dakika sonra, Görsel Analog Skala (0$100 \mathrm{~mm}$ ) ve 5-Nokta Sözel Derecelendirme Ölçeği ile ölçüldü.

Bulgular: Her iki tedavi grubu da yaș, cinsiyet ve bașlangıçtaki ağrı șiddeti yönlerinden analiz edildiğinde homojendi. Her iki tedavi de iyi tolere edildi ve gözlenen yan etkilerin hiçbiri ciddi değildi. Metamizol sodyum grubunda beș, diklofenak grubunda ise üç hasta ek tedaviye ihtiyaç duydu. Ölçülen tüm zaman noktaları için gruplar arasındaki ortalama ağrı şiddeti farkı anlamlı değildi. Her iki ilaç için de hekim ve hasta değerlendirmeleri arasında anlamlı fark yoktu.

'Medical School of Kırıkkale University, Department of Medical Pharmacology, Kırıkkale

${ }^{2}$ Medical School of Ankara University, Department of Medical Pharmacology, Ankara

DOI ID : 10.5505/TurkHijyen.2018.32848

Derici MK, Ergün H. Short-term use of metamizole sodium versus diclofenac sodium in acute renal colic pain in turkish patients; a double-blind, observational study. Turk Hij Den Biyol Derg, 2019; 76(1): 15-22 
Conclusion: Our results indicate that i.m. $1 \mathrm{~g}$ metamizole sodium is equally effective as i.m. $75 \mathrm{mg}$ diclofenac sodium for two hours of observation period in acute renal colic treatment.

Key Words: Renal colic, metamizole sodium, diclofenac sodium
Sonuç: Sonuçlarımız akut renal kolik tedavisinde i.m. $1 \mathrm{~g}$ metamizol sodyumun, iki saatlik gözlem dönemi için i.m. 75 mg diklofenak sodyum kadar etkili olduğunu göstermektedir.

Anahtar Kelimeler: Renal kolik, metamizol sodyum, diklofenak sodyum

\section{INTRODUCTION}

Renal colic is one of the most frequent reasons for emergency department visits. Clinically the pain intensity is very high and needs to be treated immediately with appropriate analgesics. In available countries such as Turkey, Brazil and Spain, metamizole sodium (dipyrone) is one of the most frequently used first line analgesic agents for colic pain (1). Another first line drug is diclofenac and is also employed commonly in renal colic pain by parenteral route (1)

Due to the high intensity of pain in renal colic, the main goal of the physicians is to decrease the pain intensity as soon as possible. In emergency service conditions, diclofenac sodium is the drug of choice in the management of renal colic pain.

However, it has been reported recently that Increased side effects such as dyspeptic complaints, nausea and gastrointestinal (GI) irritation, as well as reporting of GI bleeding, hypertension, stroke, tissue necrosis (2), cardiac symptoms (3), and different degrees of anaphylactic reactions (4-6) have led to the re-emergence of alternative therapies $(7,8)$. In early and recent discussions, there are arguments that metamizole sodium at a standard dose of $1 \mathrm{~g}$ fails to effect immediately (9-11). A search in the literature about comparative studies shows that there are conflicting results $(1,12-14)$. In a study different i.m. doses of metamizole sodium $(1 \mathrm{~g}, 2 \mathrm{~g})$ and diclofenac sodium (75 mg) were found equally effective (15). However in a meta-analysis by Edwards et al. It is stated that single dose metamizole sodium was of similar efficacy to other analgesics used in renal colic pain although intramuscular metamizole sodium was less effective than diclofenac $75 \mathrm{mg}$ (1).

In the present study we designed the study protocol to compare the efficacy and safety of the most common employed drugs metamizole sodium and diclofenac sodium and to evaluate the current practice of urinary colic pain management in a double-blind, observational, two-center study design.

\section{MATERIAL and METHOD}

This double-blind observational study was conducted after Institutional review board approval, in the emergency services of Numune State and ibn- $i$ Sina University Hospitals in Ankara, Turkey. The study was performed in accordance with the Declaration of Helsinki.

\section{Subjects and inclusion criteria}

During the data collection period of our study (two months) patients who were diagnosed with renal colic and received only metamizole or only diclofenac treatment were admitted to the study. The primary emergency department physicians were aware of the study, but they were asked not to be affected in choosing any treatment option for acute 
renal colic pain management. They were asked to continue their daily practice and gave their decision as if there was not any study conducted.

Total of 88 adult patients including male $(n=53)$ and female $(n=35)$ with renal colic pain, aged between 18 - 65, were enrolled in the study. Renal colic was diagnosed with clinical features, urine analysis and $X$-Ray examinations. Only those patients who received an order of either metamizole sodium (1 g, i.m.) or diclofenac sodium (75 mg, i.m.) were enrolled for the next 2 hours of observation period. Since another aim of the study was to evaluate the current practice, was not prepared randomization schema for the study. Treatment order was decided by the physicians who were not involved in data collection, and work full time in the emergency department service. The physicians of emergency department performed the examination, decided which of the drug were appropriate for the patient, gave the order and was responsible for the primary patient care, while the other physician who was uninformed about treatment was responsible for data collection during the whole study period. Rescue treatment need or any other medical interventions were decided by the emergency department physicians, as well. Data obtained from the patients who needed rescue treatment were not included, since some of them received their rescue medication before the two hours observation period. The final distribution of the patients in the study groups were demonstrated in Figure 1.

\section{Exclusion criteria}

Patients were excluded if they had pre-treatment with any spasmolytic or analgesic drug in the previous 12-hours, contraindications for the usage of metamizole sodium or any other NSAIDs, any preexisting disease or conditions and/or any concomitant

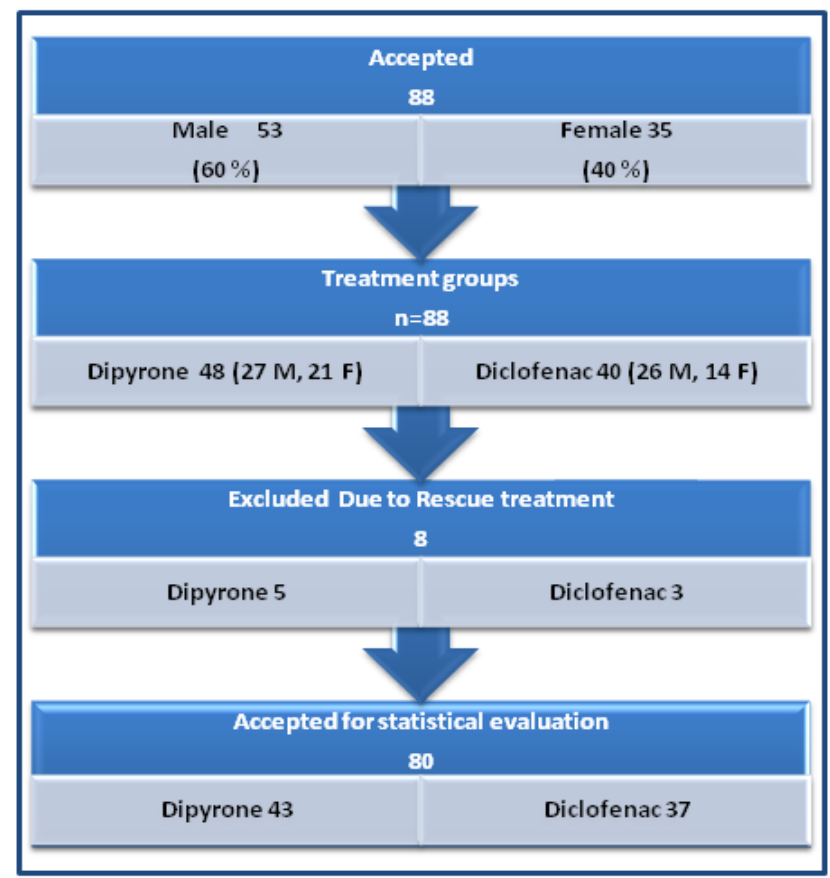

Figure 1. Distribution of the patients in the study groups. Total of 88 adult patients including male $(n=52)$ and female $(n=36)$ patients with renal colic pain, aged between $18-65$, were enrolled in the study. Forty-eight of (55\%) patients received metamizole sodium $1 \mathrm{gr}$ and $40(45 \%)$ of patients received diclofenac sodium $75 \mathrm{mg}$ via i.m. route. Rescue treatment was required for 5 patients (10\%) in metamizole sodium group and in 3 patients $(8 \%)$ in diclofenac sodium group. Data obtained from the patients who needed rescue medicine were not included in final statistical evaluation 
therapy that may interfere with the mode of action of the study drugs. Patients with impaired compliance were excluded from the trial as well.

\section{Pain measurement}

Pain intensity was measured by using visual analogue scale $(0-100 \mathrm{~mm})$ and 5-point verbal score before (baseline) and after 30, 60, 90 and 120 minutes of i.m. drug administration. The visual analog scale was a $100 \mathrm{~mm}$ long horizontal line with marked on both ends as " 0 " (no pain), and "100" (the worst pain that can be imagined). The verbal score points were as follows: 0 : no pain, 1: mild pain, 2: moderate pain, 3: severe pain, 4: very severe pain. Blood pressure was also monitorized synchronously at the pain measurement time points.

Patients were observed for at least 2 hours. The data of the patients who did not respond to the study medication and who needed a rescue treatment (according to the primary emergency department physician) was excluded from further analysis.

\section{Patient and physicians satisfaction}

At the end of the observation period ( 2 hours), both the patient and the investigator (observing physician, $\mathrm{n}=4$ ) were asked to evaluate the effectiveness of the study drug by using a 4-point rating scale: not effective (1), slightly effective (2), effective (3), very effective (4) and excellent (5).

\section{Statistical methods}

Age distribution, patient and physician satisfaction and pain scores (VAS and verbal scores) for both groups were analyzed using the unpaired Student's t test. The Kolmogorov-Smirnov test (with Lilliefors' correction) has been used to test data for normality of the population. A p value of less than 0,05 was considered significant. The Pearson Product Moment Correlation Test has been performed for measuring the correlation between the methods used to measure the pain intensity.

\section{RESULTS}

Total of 88 adult patients including, 35 female (40\%) and 53 male (60\%) were enrolled into the study. Sex, age and baseline pain intensities were not significantly different in either of the treatment groups or between the study centers. The demographic data for both groups were tabulated in Table 1 .

Table 1. Demographic data of the enrolled patients

\begin{tabular}{l|ccc}
\hline Group & $n$ & Gender & Age $( \pm$ SD) \\
\hline Metamizole sodium & 48 & $27 \mathrm{M}, 21 \mathrm{~F}$ & $33,7 \pm 11,7$ \\
Diclofenac & 40 & $26 \mathrm{M}, 14 \mathrm{~F}$ & $36,4 \pm 11,2$ \\
\hline
\end{tabular}

M: Male , F: Female , $\mathrm{n}$ : Number of patients

Forty-eight (55\%) patients received metamizole sodium $1 \mathrm{gr}$ and 40 (45\%) patients received diclofenac sodium $75 \mathrm{mg}$ via i.m. route.

Rescue treatment was required for five patients (10\%) of metamizole sodium group and for three patients (8\%) of diclofenac sodium group.

The differences between the treatment groups were insignificant for all time points measured. Neither the results of the visual analogue scale nor the 5-point verbal score showed difference between the two treatment groups (Figure 2 and 3). There was a good correlation between the methods used to measure the pain intensity $(r=0,93)$

The evaluation of the study drugs by the patient and the investigator, who was uninformed about study drugs, did not differ between the two groups. The average patient satisfaction scores $( \pm$ SEM) were 3,88 $(0,10)$ and $4,11(0,11)$ for metamizole sodium and diclofenac groups, respectively. The average physician satisfaction scores $( \pm$ SEM) were $4,09(0,07)$ and 4,30 $(0,11)$ for metamizole sodium and diclofenac groups, respectively. The median score for both patient and physician satisfaction score for both groups was 4 .

Both treatments were well tolerated and none of the observed side effects were serious. None of the patients in each group had any significant blood pressure change. 


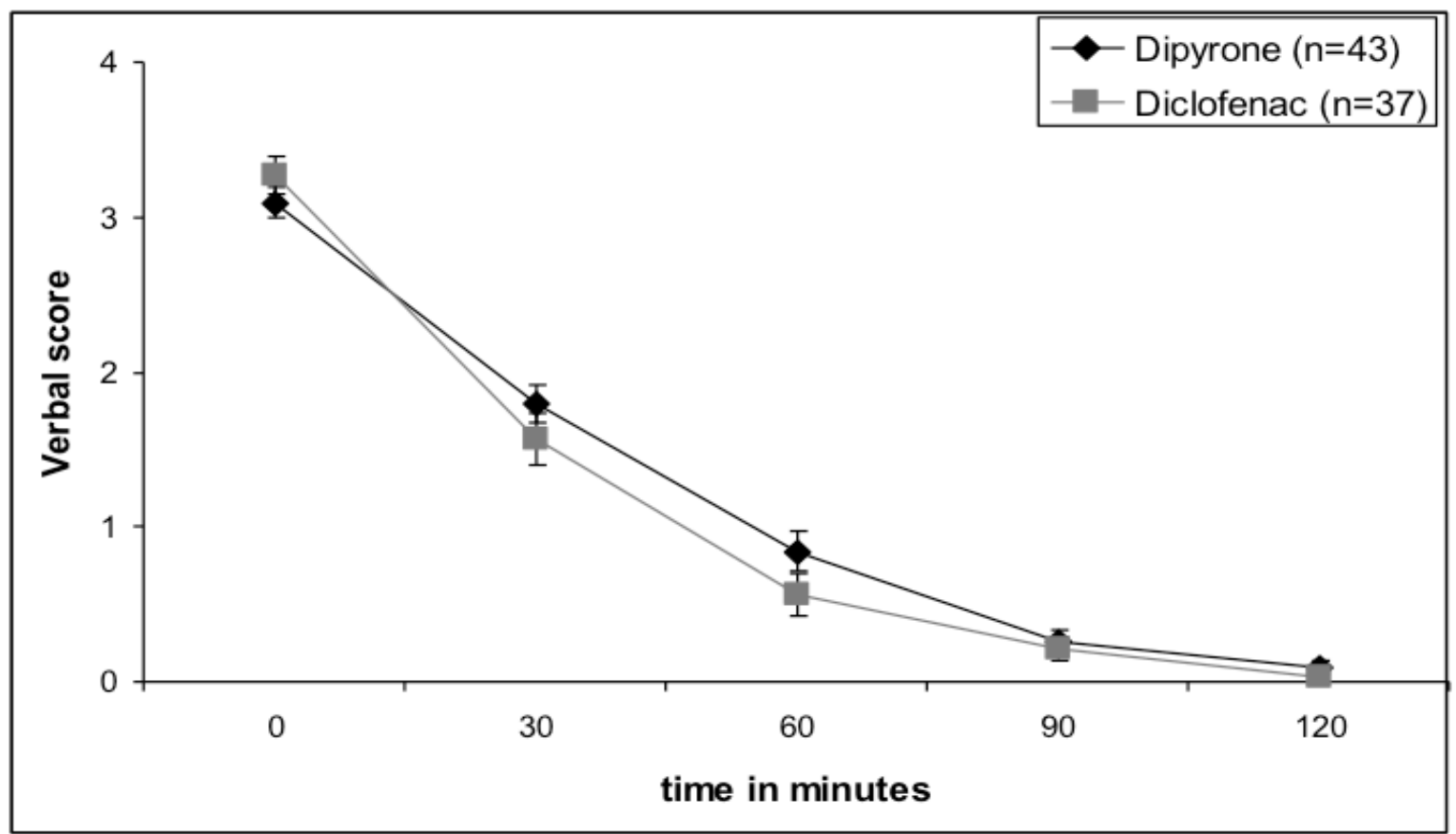

Figure 2. Time course of pain intensity measured by verbal scale (0: no pain; 4 : worst pain score) after i.m. injection of dipyrone sodium $(1 \mathrm{~g})$ or diclofenac sodium $(75 \mathrm{mg})$. Time-zero indicates the baseline pain intensity. Data are mean values $( \pm$ S.E.M) of verbal scale score of 37 patients for diclofenac group and 43 patients for dipyrone group.

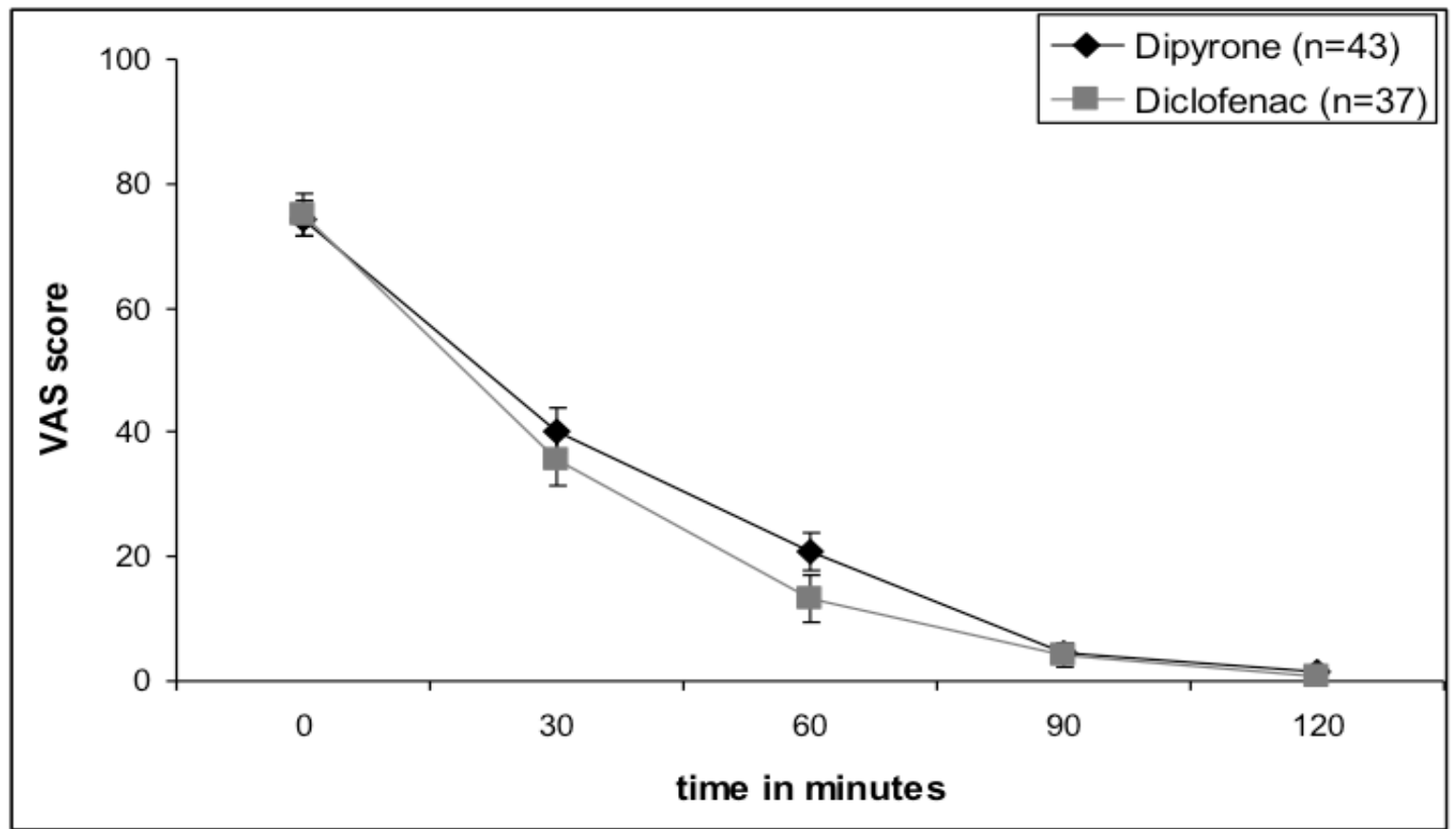

Figure 3 . Time course of pain intensity measured by visual analogue scale $(100 \mathrm{~mm})$ after i.m. injection of dipyrone sodium $(1 \mathrm{~g})$ or diclofenac sodium $(75 \mathrm{mg})$. Time-zero indicates the baseline pain intensity. Data are mean values $( \pm$ S.E.M) of verbal score of 37 patients for diclofenac group and 43 patients for dipyrone group. 


\section{DISCUSSION}

In a previous study, metamizole sodium $(1 \mathrm{~g})$ and diclofenac sodium $(75 \mathrm{mg}$ ) were compared in acute renal colic and the efficacies of the drugs were found to be equipotent (15). In the same study, another group of patients received $2 \mathrm{~g}$ of metamizole sodium and the efficacies of the drug was found almost equivalent to $1 \mathrm{~g}$ metamizole sodium and $75 \mathrm{mg}$ diclofenac sodium (15). Therefore, this study was designed in two groups as $1 \mathrm{~g}$ metamizole sodium and $75 \mathrm{mg}$ diclofenac sodium via i.m. route, which are also the daily practices in most of the emergency departments in Turkey.

Despite intense studies $(12,14-17)$ and a metaanalysis (1), there is still some debate on the effectiveness of metamizole sodium in urinary colic pain management in Turkey. Since most of the discussions are based on the personal experience of some physicians and there is not any evidence on the lower efficacy of metamizole sodium was conducted the present observational trial. There may some reasons for these experiences. For instance; almost all of the studies were conducted in other countries and since pain is a subjective sensation, it can be affected by cultural and ethnic factors, therefore the results may be different for Turkish population.

Another point is the pharmacogenetic variations in drug efficacy. In the past few decades, studies in pharmacogenetics have uncovered significant differences among various racial and ethnic groups, in metabolism, clinical effectiveness, and adverseeffect profiles of many clinically important drugs (18). In recent years, the polymorphism of drug metabolizing enzymes has been investigated among the Turkish population (19). With the data obtained it has been concluded that the frequency of the polymorphism in Turkish population is similar to other Caucasian populations (19). However, since it is not exactly known which of the metabolites of metamizole sodium are active or which of the many metabolizing isoenzymes (CYP-P450 isoenzymes) are responsible in metamizole sodium metabolism to produce its analgesic effect, it is not possible to speculate on this issue. However the results of the present and previous studies were not in favor for such a special pharmacogenetic variation for Turkish population (20). The present results are in accordance with the previously reported studies. As a result and $1 \mathrm{~g}$ i.m. metamizole sodium was found to be as effective as $75 \mathrm{mg}$ i.m. diclofenac $(21,22)$.

Some of the pharmaceutical preparations of metamizole sodium were in combinations with smooth muscle relaxant agents (i.e. hyoscine$\mathrm{N}$-butyl bromur) in the past. In clinical practice those combined pharmaceutical forms of metamizole sodium were used widely for colic pain. After the evaluation of metamizole sodium's self smooth muscle relaxant effect, and the minor beneficial contribution of the additional smooth muscle relaxant agents, the combined pharmaceutical formulations of metamizole sodium were changed to a single preparations (17, 23-25). However, this change resulted in more frequent use of $1 \mathrm{~g}$ of metamizole sodium instead of $2.5 \mathrm{~g}$, which was the dosage of the combined preparation. Even though it has been found that $1 \mathrm{~g}$ of metamizole sodium is as effective as $2 \mathrm{~g}$ metamizole sodium in pain management in the previous studies, it is obvious that lowering the dosage will effect the onset and as well as the duration of the efficacy of the drug (16). In the present study, we found that the analgesic action of metamizole sodium becomes apparent slightly slower than diclofenac. This may be the reason why the physicians have the misperception that metamizole sodium is less effective than diclofenac, as they are primarily focused on the immediate pain relief.

In the study, pain measurement time points were set at standard minutes after drug intake $(30,60$, 90 and 120 minutes). There was not any statistically significant difference at these time points between the treatment groups. However, any differences which 
will appear between the measured time points and affect the physician's opinion about the effectiveness can not be excluded. Metamizole sodium (1 g) and diclofenac sodium $(75 \mathrm{~g})$ tmax values after i.m. injection are $1,7 \mathrm{~h}$ and $0,5 \mathrm{~h}$, respectively $(26,27)$. This shows that diclofenac has an advantage for a faster absorption and onset of action. However, this was not apparent on the results obtained in this study.

Beside the treatment of pain there are several other points, which need to be considered in clinical practice. Adverse effects of NSAIDs are very common and some of them are serious. In our comparative study no serious adverse events were reported in both groups. However, in a comparative study evaluating the safety of non-narcotic analgesics (metamizole sodium, aspirin, diclofenac and paracetamol) after their use for short periods of time, showed that the excess mortality attributed to each of these drugs were as follows: metamizole sodium - 25/100 million, aspirin - 185/100 million, diclofenac 592/100 million, paracetamol - 20/100 million (28). This results indicates that the adverse effects should always be kept in mind in addition to their efficacy.

Another important point in renal colic pain management is the cost of the overall treatment. Especially for frequently seen disorders it has a tremendous impact from the societal perspective. Small differences in cost are growing with the high prevalence rate. In our study, design of the pharmacoeconomic impact of these treatment options was not analyzed. However, a rough cost analysis of a single injection of metamizole sodium or diclofenac showed that metamizole sodium has an apparent lower cost than diclofenac sodium.

In this study, $1 \mathrm{~g}$ metamizole sodium, which is $13 \%$ of the daily maximum and $33 \%$ of a single therapeutic dose was used. In contrast, $75 \mathrm{mg}$ diclofenac sodium is $50 \%$ of the daily maximum and $100 \%$ of a single therapeutic dose. This provides an advantage when metamizole sodium is employed for both the patient and the physician to continue with the same drug after initial treatment, when needed.

In conclusion, Turkish experience of acute renal colic pain treatment in the emergency departments is reported. Data obtained in this study indicates that metamizole sodium $(1 \mathrm{~g})$ is as effective as diclofenac sodium (75 mg) after i.m. injection in renal colic pain patients.

\section{REFERENCES}

1. Edwards JE, Meseguer F, Faura C, Moore RA, McQuay HJ. Single dose dipyrone for acute renal colic pain. Cochrane Database Syst Rev. 2002; (4):CD003867.

2. Giovannetti $M$, Machado $M A$, Borrelli Júnior $M$, Ikejiri Cl, Alonso N, Branco PD. Tissue necrosis: a side effect of sodium diclofenac: report of cases and discussion of the physiopathology. Rev Hosp Clin Fac Med Sao Paulo. 1993;48(1):39-42.

3. Cagliyan CE, Balli M, Tekin K, Turkmen S, Tanboga HI. Kounis syndrome triggered by diclofenac sodium injection which leads to myocardial infarction and cardiac arrest. Journal of Cardiology Cases.2013;8(1):e17-e19.
4. Singh R, Bansal D, Baduni N, Vajifdar $H$. Anaphylactic reaction to intravenous diclofenac. Indian J Crit Care Med 2011;15:37-9.

5. Neki N, Sharma R, Gupta S, Gupta H, Manie T. Case Report_Anaphylactic Reaction to Intramuscular Diclofenac. Case Reports from the Tropics. 2013;1(1): e2.

6. Colak S, Gunes H, Afacan MA, Kandis H, Erdogan MO, Ayranci M, Saritas A. Anaphylaxis after intramuscular injection of diclofenac sodium. Am J Emerg Med. 2014 Jul;32(7):815.e1-2. doi: 10.1016/j.ajem.2013.12.049. 
7. Godara S., Srivastava R., Vashist M., \& Godara R. Lornoxicam versus diclofenac sodium in acute renal colic: a prospective randomized trial. International Journal of Basic \& Clinical Pharmacology. 2017;2(2):193-198.

8. Shams-Vahdati S, Robaei N, Habibollah P, JafariRouhi A , Mohammadi S, et al. Paracetamol vs. Intravenous Morphine Plus Diclofenac in Renal Colic Pain: A Randomized Clinical Trial, NephroUrol Mon. 2018;10(4):e77193. doi: 10.5812/ numonthly.77193.

9. Pathan SA, Mitra B, Cameron PA. A Systematic review and meta-analysis comparing the efficacy of nonsteroidal anti-inflammatory drugs, opioids, and paracetamol in the treatment of acute renal colic. Eur Urol. $2018 ; 73(4): 583-595$. doi: 10.1016/j. eururo.2017.11.001.

10. Garcća-Alonso Dr. F. Comparative study of the efficacy of dipyrone, diclofenac sodium and pethidine in acute renal colic. European Journal of Clinical Pharmacology 40 (2004): 543-6.

11. Kötter $T$, da Costa BR, Fässler M, Blozik E, Linde $K$, Jüni $P$, et al. Metamizole-Associated. Adverse events: A systematic review and metaAnalysis. PLoS ONE. 2015;10(4): e0122918. doi:10.1371/ journal.pone. 0122918 .

12. Miralles R, Cami J, Gutierrez J, Torne J, Garces JM, Badenas JM. Diclofenac versus dipyrone in acute renal colic: a double-blind controlled trial. Eur J Clin Pharmacol. 1987; 33(5):527-8.

13. Marthak KV, Gokarn AM, Rao AV, Sane SP, Mahanta RK, Sheth RD, Chavda KD, Rane BS, Vaidya AB. A multi-centre comparative study of diclofenac sodium and a dipyrone/spasmolytic combination, and a single-centre comparative study of diclofenac sodium and pethidine in renal colic patients in India. Curr Med Res Opin. 1991; 12(6):366-73.

14. Collaborative Group of the Spanish Society of Clinical Pharmacology. Comparative study of the efficacy of dipyrone, diclofenac sodium and pethidine in acute renal colic. Eur J Clin Pharmacol. 1991; 40(6):543-6.

15. EMuriel-Villoria C, Zungri-Telo E, Diaz-Curiel M, Fernandez-Guerrero M, Moreno J, Puerta J, Ortiz P. Comparison of the onset and duration of the analgesic effect of dipyrone, 1 or $2 \mathrm{~g}$, by the intramuscular or intravenous route, in acute renal colic. Eur J Clin Pharmacol. 1995; 48(2):103-7.

16. Muriel C, Ortiz P. Efficacy of two different intramuscular doses of dipyrone in acute renal colic. Cooperative Study Group. Methods Find Exp Clin Pharmacol. 1993; 15(7):465-9.
17. Sanahuja J, Corbera G, Garau J, Pla R, Carmen Carre M. Intramuscular diclofenac sodium versus intravenous Baralgin in the treatment of renal colic. DICP. 1990; 24(4):361-4.

18. Burroughs VJ, Maxey RW, Levy RA. Racial and ethnic differences in response to medicines: towards individualized pharmaceutical treatment. J Natl Med Assoc. 2002; 94(10 Suppl):1-26.

19. Babaoglu MO, Yasar U, Sandberg M, Eliasson E, Dahl ML, Kayaalp SO, Bozkurt A. CYP2C9 genetic variants and losartan oxidation in a Turkish population. Eur J Clin Pharmacol. 2004; 60(5):337-42.

20. Tulunay FC, Ergün H, Gülmez SE, Özbenli $T$, Özmenoğlu M, Boz C, Erdemoglu AK, Varlıkbaș A, Göksan B, Inan L. The efficacy and safety of dipyrone (Novalgin $\otimes)$ tablets in the treatment of acute migraine attacks: A double-blind, crossover, randomized, placebo-controlled multi-center study. Funct Neurol 2004, 19(3):197-202.

21. Saray A, Buyukkocak U, Cinel I, Tellioglu AT, Oral $\mathrm{U}$. Diclofenac and metamizol in postoperative analgesia in plastic surgery. Acta Chir Plast. 2001; 43(3):71-6.

22. Koçyiğit ID, Gülmez SE, Kaya M, Ergün H, Mocan A, Tulunay FC. Efficacy \& safety of preemptive Celecoxib, Rofecoxib or dipyrone treatment in third molar surgery: A preliminary report. Clin Exp Pharmacol Physiol. 2004; 31 Suppl 1: A67.

23. Zwergel $U$, Felgner $\mathrm{J}$, Rombach $\mathrm{H}$, Zwergel $\mathrm{T}$. Current conservative treatment of renal colic: value of prostaglandin synthesis inhibitors Schmerz. 1998; 12(2):112-7.

24. Lloret J, Munoz J, Monmany J, Puig X, Bonastre M, Brau J, Sola J, Domingo P, Jane F. Treatment of renal colic with dipyrone. Curr Ther Res. 1987; 42(6):1119-1128

25. Ergun H, Ayhan IH, Tulunay FC. Pharmacological characterization of metamizol-induced relaxation in phenylephrine-precontracted rabbit thoracic aorta smooth muscle. Gen Pharmacol. 1999; 33(3):237-41

26. Levy M, Zylber-Katz E, Rosenkranz B. Clinical pharmacokinetics of dipyrone and its metabolites. Clin Pharmacokinet. 1995; 28(3):216-34.

27. Kurowski M. Pharmacokinetics and biological availability of diclofenac preparations following intramuscular injection of $75 \mathrm{mg}$ and oral administration of $150 \mathrm{mg}$ of active drug. Z Rheumatol. 1988; 47(1):37-42.

28. Andrade SE, Martinez C, Walker AM. Comparative safety evaluation of non-narcotic analgesics. J Clin Epidemiol. 1998; 51(12):1357-65. 